\title{
Pengaruh Pembiasaan, Kecerdasan Emosional dan Dukungan Orang Tua Terhadap Kemandirian Anak
}

\author{
Wahyuni $^{1}{ }^{\bowtie}$, Harun Al Rasyid ${ }^{1}$ \\ Pendidikan Anak Usia Dini, Universitas Negeri Yogyakarta, Indonesia(1) \\ DOI: $\underline{10.31004 / o b s e s i . v 6 i 4.2301}$
}

\begin{abstract}
Abstrak
Kemandirian anak dapat dipengaruhi oleh faktor instrinsik seperti: kondisi fisik, bakat, minat, motivasi, IQ, emosi, dan kepribadian; dan faktor ekstrinsik seperti: pola asuh orang tua, budaya sekolah, kondisi masyarakat dan teman sebaya. Tujuan penelitian ini untuk menganalisis pengaruh pembiasaan, kecerdasan emosi, dan dukungan orang tua terhadap kemandirian anak. Jenis penelitian adalah kuantitatif. Penelitian dilakukan pada 5 TK/RA dengan jumlah peserta didik 266 anak, dan jumlah sampel yang diambil adalah 160 anak, yang dihitung berdasarkan rumus Tara Yamane dengan presisi 5\%. Teknik pengumpulan data menggunakan kuesioner dan dokumentasi. Teknik analisis data menggunakan regresi linier berganda. Hasil penelitian menyimpulkan bahwa pembiasaan, kecerdasan emosi, dan dukungan orang tua berpengaruh terhadap kemandirian anak baik secara parsial maupun secara simultan. Temuan ini berimplikasi bahwa untuk meningkatkan kemandirian anak, orang tua harus membiasakan perilaku yang baik kepada anak, mendorong anak untuk dapat bergaul dengan teman sebayanya, dan orang tua harus selalu memberikan dukungan atau memberikan penguatan positif kepada anak.
\end{abstract}

Kata kunci: pembiasaan; kecerdasan emosi; dukungan orang tua; kemandirian anak

\begin{abstract}
Children's independence can be influenced by intrinsic factors such as: physical condition, talents, interests, motivation, IQ, emotions, and personality; and extrinsic factors such as: parenting patterns, school culture, community conditions and peers. The purpose of this study was to analyze the effect of habituation, emotional intelligence, and parental support on children's independence. This type of research is quantitative. The study was conducted in 5 TK/RA with a total of 266 students, and the number of samples taken was 160 children, which was calculated based on the Tara Yamane formula with a precision of 5\%. Data collection techniques using questionnaires and documentation. The data analysis technique used multiple linear regression. The results of the study concluded that habituation, emotional intelligence, and parental support had an effect on children's independence either partially or simultaneously. This finding implies that to increase children's independence, parents or teachers must familiarize children with good behavior, encourage children to get along with their peers, and parents must always provide support or provide positive reinforcement to children.
\end{abstract}

Keywords: habituation; emotional intelligence; parental support; children's independence

Copyright (c) 2022 Wahyuni, Harun Al Rasyid

$\triangle$ Corresponding author :

Email Address : wahyunitk69@gmail.com (Yogyakarta, Indonesia)

Received 18 November 2021, Accepted 10 February 2022, Published 14 February 2022 


\section{PENDAHULUAN}

Masa usia dini merupakan masa penting dimana pada masa ini ada era yang dikenal dengan masa keemasan (golden age). Masa keemasan hanya terjadi satu kali dalam perkembangan kehidupan manusia (Sit, 2015). Pada masa ini merupakan masa kritis bagi perkembangan anak. Perkembangan anak usia dini mencakup berbagai aspek. Pada Peraturan Menteri Pendidikan dan Kebudayaan Nomor 146 tahun 2014 tentang Kurikulum 2013 Pendidikan Anak Usia Dini pada pasal 5 dinyatakan bahwa aspek-aspek pengembangan dalam kurikulum PAUD mencakup: nilai agama, nilai moral, fisik-motorik, kognitif, bahasa, sosial-emosional, dan seni. Santrock menyatakan perkembangan anak usia dini mencakup aspek perkembangan fisik, kognitif, sosial-emosional, konteks sosial, moral, bahasa, identitas diri, dan gender (Sit, 2015). Kail dan Reese menjelaskan bahwa ruang lingkup perkembangan anak usia dini mencakup perkembangan kemandirian, moral, sosial, bahasa, fisik, dan kognitif (Sit, 2015).

Perilaku mandiri memiliki peran penting bagi anak usia dini yakni untuk membantu agar anak mampu melakukan segala sesuatu sendiri tanpa memerlukan bantuan orang lain, sehingga anak tidak akan membebani orang-orang yang hidup di sekitarnya. Pembentukkan perilaku mandiri sangat penting untuk diterapkan pada setiap individu sejak dini karena dengan terbentuknya karakter mandiri pada setiap individu akan meminimalisir terjadinya penyimpangan perilaku yang sering terjadi saat ini terutama pada anak usia 5-6 tahun (Susanto, 2018).

Berdasarkan observasi di TK Pertiwi Keden Pedan Klaten, peneliti menemukan contoh kecil dari penyimpangan perilaku yang dilakukan anak usia dini usia 5-6 tahun. Misalnya memukul salah satu temannya karena tidak diajak bermain. Mengambil bekal makanan teman tanpa meminta izin. Mencuci tangan sebelum dan sesudah makan tetapi masih dalam keadaan kotor, makan sambil berbicara, makan tidak teratur dan belum bisa menalikan tali sepatunya sendiri. Juga terdapat sebagian anak masih tertukar dalam memakai sepatu, dan terdapatnya sebagian anak yang masih ingin ditunggu oleh orang tuanya ketika mengikuti kegiatan pembelajaran. Hal tersebut merupakan bukti belum terbentuknya karakter mandiri dalam diri anak. Oleh karena itu, anak TK usia 5-6 perlu memiliki kemandirian agar saat memasuki sekolah dasar, anak tersebut sudah tidak ditunggui oleh orang tuanya, dapat ke toilet sendiri, memakai sepatu sendiri, dapat bergaul dengan temannya, dan mengerjakan sendiri tugas yang diberikan sekolah.

Rendahnya kemandirian pada anak usia dini merupakan kendala bagi anak untuk mengikuti pendidikan yang lebih tinggi. Oleh sebab itu, pentingnya ditanamkan kemandirian pada anak sejak dini karena dengan melatih anak mandiri, anak tidak akan mudah bergantung pada orang lain dan dapat tumbuh menjadi anak yang memiliki jiwa yang kuat serta membentuk kepribadian yang unggul. Dengan ditanamkannya kemandirian sejak dini, maka ketika dewasa anak akan lebih mudah dalam mengambil keputusan, bertanggung jawab, tidak mudah bergantung pada orang lain, dan mampu menyesuaikan diri dengan lingkungannya (Sa'diyah, 2017). Kemandirian penting bagi anak, karena kemandirian merupakan ciri dari pribadi yang sehat. Hal ini seperti yang dijelaksan oleh Yusuf (2019) bahwa kemandirian merupakan karakteristik dari kepribadian yang sehat (healthy personality). Kemandirian individu tercermin dari cara berpikir dan bertindak, mampu mengambil keputusan, mengarahkan dan mengembangkan diri, serta menyesuaikan diri secara konstruktif dengan norma yang berlaku di lingkungannya.

Oleh karena itu, orang tua wajib mengasuh dan melindungi anak tetapi tidak berarti orang tua mengambil alih setiap permasalahan anak. Orang tua yang sering kali ikut campur tangan dan menyelesaikan permasalahn anak sebenarnya kurang mendidik anak untuk bersikap mandiri dan tanggung jawab. Orang tua dapat membina anak untuk menjadi mandiri dan bertanggung jawab terhadap segala perbuatanya. Kemandirian dan tanggung jawab tidak hanya berlalu pada orang dewasa saja melainkan pada setiap tingkatan usia. Setiap manusia perlu mengembangkan kemandirian dan melaksanakan tanggung jawab 
sesuai dengan kapasitas dan tahapan perkembanganya. Sebenarnya sejak dini secara alamiah anak mempunyai dorongan untuk mandiri dan bertanggung jawab atas dirinya sendiri (Kusumaningtyas, 2015). Temuan penelitian Purnama \& Hidayati (2020) menyimpulkan bahwa indikator-indikator pengasuhan anak dapat direduksi dari data inti aspek-aspek pengasuhan yaitu asuh, asih, dan asah. Anhusadar \& Islamiyah menambahkan bahwa pola asuh adalah cara orang tua mendidik anak dan membesarkan anak yang dipengaruhi oleh banyak faktor, antara lain faktor budaya, agama, kebiasaan dan kepercayaan, serta kepribadian orang tua (orang tua sendiri atau orang yang mengasuh anak (Anhusadar \& Islamiyah, 2021).

Kemandirian anak akan tercapai apabila orang tua melakukan upaya melalui berbagai kegiatan yang menunjang pengembangan kemandirian anak. Dengan pola asuh orang tua yang baik, anak akan berkembang dalam aspek kemandiriannya. Orang tua harus melatih kemandirian anak sejak dini agar anak tidak tergantung pada orang lain. Anak juga akan terbiasa mandiri dalam melakukan kegiatan-kegiatan apapun. Orang-orang yang berperan penting dalam menumbuh kembangkan kemandirian anak adalah pola asuh orang tua/keluarga, lingkungan sosial, dan teman sebaya (sesama anak). Karena semua orang tua ingin mendidik anaknya dengan baik supaya bisa mandiri dan bertanggung jawab atas segala perbuatannya.

Anak usia 5-6 tahun seharusnya sudah mampu untuk melakukan aktifitas sendiri, mengatur dalam memilih dan menetukan tindakan sendiri, mampu menyelesaikan masalah berdasarkan inisiatif dan juga dapat menjelajahi lingkungan sekitarnya. Adapun kenyataan yang terlihat di lingkungan TK atau PAUD belum semua anak mampu melakukan kegiatan secara mandiri (F. Hayati \& Hanum, 2017). Sebagian dari mereka masih memerlukan bantuan dari orang yang lebih dewasa untuk memenuhi keperluannya seperti makan, minum, memakai pakaian, memakai kaos kaki, memakai sepatu, membereskan mainan dan merapikan peralatan sekolahnya. Dalam hal ini terlihat bahwa kemandirian anak masih rendah, anak masih bergantung pada orang yang lebih dewasa untuk memenuhi kebutuhannya sehari-hari. Berdasarkan hasil penelitian (Sari et al., 2019) ditemukan bahwa dari 6 kelas, hampir seluruh kelas mencapai 75\% lebih menunjukkan adanya masalah dalam kemandirian, dimana masih banyak anak yang mengeluh, pemalu, cengeng, penakut, pencemas, selalu ingin ditemani oleh orang tuanya dan manja. Penelitian Setiani \& Setyo (2014) juga menemukan bahwa terdapat beberapa anak yang masih kesulitan dalam menali tali sepatu, masih memerlukan bantuan dalam mengkancingkan baju ketika memakai kostum maupun ketika kancing seragam anak lepas dan anak belum mampu makan sendiri dengan rapi dan benar.

Kemandirian anak dapat dipengaruhi oleh beberapa faktor, diantaranya adalah pembiasaan. Nucci menjelaskan bahwa proses pembelajaran di lembaga PAUD berlangsung sejak anak-anak hadir di sekolah sampai anak-anak kembali kepada orangtua. Dengan demikian pembentukan karakter dapat dikemas dalam berbagai aktivitas pembelajaran. Beragam cara dapat dilakukan diantaranya melalui tauladan dan pembiasaan dalam kehidupan sehari-hari (Srianita et al., 2020). Lickona memperkuat dengan mengatakan bahwa pendidikan karakter yang efektif membutuhkan pendekatan yang proaktif, komprehensif, dan harus intensif (D. Hayati, 2020).

Pembiasaan itu sendiri adalah (habituation) proses pembentukan sikap dan perilaku yang relatif menetap dan bersifat otomatis melalui proses pembelajaran yang berulang-ulang. Sikap atau perilaku yang menjadi kebiasaan mempunyai ciri; perilaku tersebut relatif menetap, umumnya tidak memerlukan fungsi berpikir yang cukup tinggi. Ramayulis (2018) menjelaskan bahwa pembiasaan adalah upaya praktis dalam pembinaan dan pembentukan mental dan akhlak. Hasil dari pembiasaan yang dilakukan oleh pendidik adalah terciptanya suatu kebiasaan bagi anak didik. Kebiasaan adalah suatu tingkah laku tertentu yang sifatnya otomatis, tanpa direncanakan terlebih dahulu, dan berlaku begitu saja tanpa dipikirkan lagi. 
Proses pembiasaan sebenarnya berintikan pengulangan. Artinya yang dibiasakan itu adalah sesuatu yang dilakukan berulang-ulang dan akhirnya menjadi kebiasaan. Pembiasaan harus diterapkan dalam kehidupan keseharian anak didik, sehingga apa yang dibiasakan terutama yang berkaitan dengan akhlak baik akan menjadi kepribadian yang sempurna. Misalnya jika guru masuk kelas selalu mengucapkan salam. Proses pembiasaan dalam pendidikan merupakan hal yang penting terutama bagi anak-anak usia dini. Anak-anak belum menyadari apa yang disebut baik dan tidak baik dalam arti susila. Ingatan anak-anak belum kuat, perhatian mereka lekas dan mudah beralih kepada hal-hal yang terbaru dan disukainya. Dalam kondisi ini mereka perlu dibiasakan dengan tingkah laku, keterampilan, kecakapan dan pola pikir tertentu. Hal ini sejalan dengan pendapat Wijayanti bahwa anak-anak yang telah dibiasakan dengan pola hidup sehat dan bersih sejak dini akan tumbuh dan berkembang dengan baik, menyenangkan dan dapat menyesuaikan diri dengan lingkungan (Wijayanti, 2020).

Selain faktor pembiasaan, faktor yang dianggap berpengaruh terhadap kemandirian anak adalah kecerdasan emosional. Hasil penelitian (Siregar, 2018) menyimpulkan bahwa kecerdasan emosional berpengaruh terhadap kemandirian santriwan sebesar $41,3 \%$ dan santriwati sebesar 33,9\%. Penelitian Hidayati (2014) juga menyimpulkan bahwa kecerdasan emosi berkorelasi dengan kemandirian. Goleman menyebutkan bahwa individu yang cerdas secara emosi mempunyai kemampuan untuk mengenali emosi diri sendiri dan orang lain, mengelola emosi diri sendiri, motivasi, mengenali emosi orang lain dan kemampuan membina hubungan (Goleman, 2016)

Menurut Shapiro (2018) kecerdasan emosional sebagai dasar kecerdasan sosial yang melibatkan kemampuan memantau perasaan dan emosi baik pada diri sendiri maupun pada orang lain, memilah-milah semuanya dan menggunakan informasi untuk membimbing pikiran dan tindakan. Kecerdasan emosional inilah yang berfungsi sebagai pengendalian diri seseorang dalam melakukan tindakan. Kecerdasan emosional diungkapkan pertama kali oleh psikolog Peter Salovy dari Harvard University dan John Mayer dari University Of New Hampshire untuk mengungkapkan kualitas-kualitas emosional yang tampaknya penting bagi keberhasilan hidup. Kualitas ini antara lain empati, mengungkapkan dan memahami perasaan, mengendalikan amarah, kemandirian, kemampuan menyesuiakan diri, kemampuan memecahkan masalah antar pribadi, ketekunan, kesetiakawanan, keramahan dan sikap hormat.

Menurut Riana berbagai penelitian dalam bidang psikologi telah membuktikan bahwa anak-anak yang memiliki kecerdasan emosi yang tinggi adalah anak-anak yang bahagia, percaya diri, populer dan sukses. Sedangkan menurut Permendikbud No 137 tahun 2014 tentang Standar Tingkat Pencapaian Perkembangan Anak (STPPA), standar pencapaian perkembangan pada aspek sosial emosional antara lain: menunjukan sikap mandiri, menunjukan rasa percaya diri, memahami peraturan dan disiplin, memiliki sikap gigih (tidak mudah menyerah), dan bangga terhadap hasil karya sendiri.

Selain faktor pembiasaan dan kecerdasan emosional, kemadirian anak juga dapat dipengaruhi oleh dukungan orang tua. Noorkasiani dalam Ningtyas (2017) menyebutkan bahwa dukungan keluarga merupakan unsur penting dalam membantu individu menyelesaikan masalah. Apabila ada dukungan, rasa percaya diri akan bertambah dan motivasi untuk mengatasi masalah yang terjadi akan meningkat. Hasil penelitian Ningtyas (2017) menyimpulkan bahwa terdapat hubungan antara dukungan keluarga dengan kemandirian activities of daily living pada anak prasekolah di KB dan TK Sanggar Sahabat Sejati Yogyakarta. Hasil penelitian Garnika \& Suarti (2018) menyimpulkan bahwa dukungan orang tua berpengaruh terhadap kemandirian anak. Hasil penelitian (Amin et al., 2021) menyimpulkan bahwa ada pengaruh positif dan signifikan antara kelekatan aman anak pada ibu terhadap kemandirian anak usia 5-6 tahun. Candra et al. menyatakan bahwa pengasuhan 
orang tua terhadap anaknya dapat berpengaruh terhadap pembentukan karakter dan perilaku anak itu sendiri. Apabila terdapat kesalahan pengasuhan maka akan berdampak pada anak saat sudah dewasa (Kurniati et al., 2021). Turney and Kao menambahkan keluarga memiliki peran yang sangat penting bagi perkembangan anak, karena keluarga merupakan tempat pertama pembentuk pengalaman anak dan yang akan membantu perkembangan anak hingga ke masa depan nanti (Siahaan et al., 2021).

Kusumaningtyas menjelaskan bahwa pada dasarnya sebagai orang tua berkewajiban untuk memberi kasih sayang dan perhatian pada anak-anaknya. Namun demikian kasih sayang dan perhatian yang diberikan pada anaknya tidak boleh terlalu berlebihan, karena dapat menghambat perkembangan kemandirian. Bagi para orang tua, mengirimkan anakanak ke sekolah sudah merupakan sebuah kewajiban yang disertai harapan-harapan agar si anak dapat memeperoleh wawasan, dunia baru, hidup bersosial, ilmu-ilmu yang intinya demi mempersiapkan mereka menghadapi masa depan mereka dengan baik. Kalau dilihat dari sisi seorang anak, pada awalnya pergi ke sekolah adalah suatu aktifitas baru dari yang biasa mereka dapatkan di seputar rumah dan orang tua, masuk ke lingkungan baru yang masih menjadi tanda tanya. Lingkungan yang biasa mereka rasakan aman di rumah, dunia yang sudah dan biasa mereka kenal sejak lahir, yang tidak banyak berhubungan dengan dunia luar. Sering ditemui hari-hari pertama anak di play group atau TK diiringi dengan tangis. Mereka memiliki ketakutan, kecemasan, kekhawatiran akan situasi baru, wawasan baru, lingkungan baru, tuntutan baru. Sebab itu, perlu bagi para orang tua mempersiapkan mereka dengan baik secara mental untuk masuk ke sekolah (Anwar \& Ahmad, 2016).

\section{METODOLOGI}

Desain penelitian menggunakan penelitian kuantitatif, yang bertujuan menguji pengaruh pembiasaan, kecerdasan emosional, dan dukungan orang tua terhadap kemandirian anak, yang diilustrasikan sebagaimana pada gambar 1.

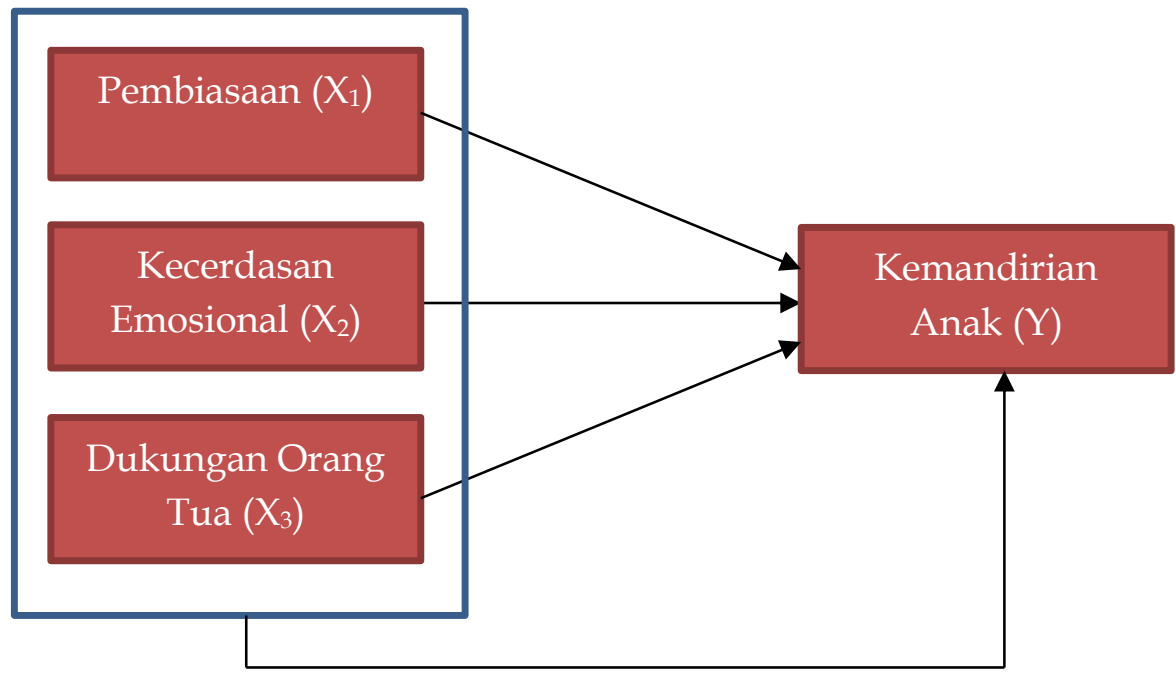

Gambar 1. Desain Penelitian

Tempat penelitian dilakukan di Gugus Alamanda Kecamatan Pedan Kabupaten Klaten. Waktu penelitian dilaksanakan selama tiga bulan, yaitu September sampai November 2021. Populasinya adalah peserta didik TK/RA yang berada di Gugus Alamanda Kecamatan Pedan Kabupaten Klaten, yang berjumlah 266 peserta didik, yang terdiri atas: TK Pertiwi Keden dengan jumlah siswa 41 anak; TK Islam Purnama dengan jumlah siswa 85 anak; TKIT AL Hawary dengan jumlah siswa 53 anak; TK Pertiwi Jetiswetan dengan jumlah siswa 13 anak; dan TK PGRI dengan jumlah siswa 74 anak. Jmlah sampel penelitian ditetapkan berdasarkan rumus Tara Yamane dalam (Hasanah, 2012) dengan presisi 5\% dan jumlah sampelnya diperoleh 159,7597 dibulatkan menjadi 160 orang (orang tua murid). Teknik 
sampling menggunakan probability sampling teknik area (cluster) sampling, yaitu sampel diambil dengan mempertimbangkan jumlah perserta didik pada setiap TK/RA. Teknik pengumpulan data menggunakan penyebaran kuesioner (angket) dan studi pustaka (dokumentasi). Teknik analisis data menggunakan regresi linier berganda, yaitu teknik analisis regresi yang dapat digunakan untuk menguji pengaruh beberapa variabel independen terhadap satu variabel dependen (Latan \& Temalagi, 2018).

\section{HASIL DAN PEMBAHASAN}

\section{Validitas dan Reliabilitas Kuesioner}

Berdasarkan uji validitas diketahui bahwa koefisien korelasi item-item pertanyaan dengan total item (Corrected Item-Total Correlation) mempunyai nilai lebih besar dari 0,3, berarti semua item adalah valid. Hal ini sesuai pendapat Masrun dalam (Sugiyono, 2013) bahwa item yang mempunyai korelasi positif dengan kriterium (skor total) serta korelasi yang tinggi, menunjukkan bahwa item tersebut mempunyai validitas yang tinggi pula. Besarnya syarat minimum untuk dianggap memenuhi syarat adalah kalau $r=0,3$. Dengan demikian, seluruh item yang digunakan untuk mengukur pembiasaan adalah valid.

Koefisien korelasi item-item pertanyaan dengan total item mempunyai nilai lebih besar dari 0,3. Hal ini berarti seluruh item yang digunakan untuk mengukur kecerdasan emosi adalah valid. Koefisien korelasi item pertanyaan nomor 4 dengan total item mempunyai nilai lebih kecil dari 0,3, yaitu 0,282. Hal ini berarti item nomor 4 dinyatakan tidak valid, dan data skor item nomor 4 selanjutnya tidak diikutkan untuk analisis selanjutnya. koefisien korelasi item-item pertanyaan dengan total item mempunyai nilai lebih besar dari 0,3. Hal ini berarti seluruh item yang digunakan untuk mengukur kemandirian anak adalah valid.

Berdasarkan hasil uji reliabilitas dengan Cronbach Alpha diketahui bahwa koefisien Cronbach Alpha untuk instrumen penelitian (kuesioner) pembiasaan $(0,888)$, kecerdasan emosi $(0,966)$, dukungan orang tua $(0,922)$, dan kemandirian anak $(0,944)$, sehingga keempat kuesioner memiliki koefisien Cronbach Alpha lebih besar dari 0,70 dan dinyatakan reliabel atau kuesioner dapat diandalkan dan dipercaya untuk mengumpulkan data (Sugiyono, 2013).

\section{Uji Asumsi Klasik}

Hasil uji multikolinieritas di atas diketahui besarnya VIF variabel pembiasaan $(2,369)$, kecerdasan emosi $(2,600)$ dan dukungan orang rua $(2,309)$ sehingga ketiganya bernilai lebih kecil dari 10. Nilai tolerance variabel pembiasaan $(0,422)$, kecerdasan emosi $(0,385)$ dan dukungan orang rua $(0,433)$ sehingga ketiganya bernilai lebih besar dari 0,1 . Dengan demikian dapat disimpulkan tidak terdapat masalah multikolinieritas.

Berdasarkan hasil uji heteroskedastisitas diketahui bahwa pada grafik scatterplots terlihat titik-titik menyebar secara acak (random) baik di atas maupun di bawah angka 0 pada sumbu Y. Selanjutnya, dengan uji Glejser diperoleh hasil bahwa pembiasaan memiliki signifikansi 0,997 >0,05, kecerdasan emosi memiliki signifikansi 0,058 >0,05 dan dukungan orang tua memiliki signifikansi $0,179>0,05$. Hal ini dapat disimpulkan bahwa variabel pembiasaan, kecerdasan emosi, dukungan orang tuai tidak terjadi permasalahan heteroskedastisitas.

Berdasarkan hasil uji normalitas diketahui bahwa pada grafik normal probability plots terlihat titik-titik menyebar berhimpit di sekitar garis diagonal dan hal ini menunjukkan bahwa residual terdistribusi secara normal. Selanjutnya berdasarkan uji Kolmogorov-Smirnov diperoleh hasil bahwa nilai signifikansi diperoleh 0,251 > 0,05. Dengan demikian, residual terdistribusi normal.

\section{Analisis Deskriptif Pembiasaan}


Berdasarkan rekap data penelitian diketahui bahwa skor tertinggi pembiasaan adalah 65 dan terendah 42. Dari skor ini kemudian dapat dibuat pengelompokkan skor menurut tinggi, sedang, dan rendah dengan cara sebagai berikut ini.

$$
\begin{aligned}
\text { Interval } & =\frac{\text { Nilai tertinggi }- \text { nilai terendah }}{3} \\
& =(65-42) / 3 \\
& =8
\end{aligned}
$$

Dengan demikian, skor data penelitian dapat dikelompokkan, yaitu :

Rendah $=$ Skor 42 sampai dengan $42+8=50$

Sedang $=$ Skor 51 sampai dengan $50+8=58$

Tinggi $=$ Skor 59 sampai dengan 65

Dari patokan tersebut kemudian masing-masing skor data penelitian dapat dikategorikan seperti pada tabel 1 dan gambar 2 .

Tabel 1 Kateori Skor Pembiasaan

\begin{tabular}{clrr}
\hline Skor & Ketagori & Frekuensi & \multicolumn{1}{c}{$\%$} \\
\hline $59-65$ & Tinggi & 41 & 25,63 \\
$51-58$ & Sedang & 108 & 67,50 \\
$42-50$ & Rendah & 11 & 6,88 \\
\hline Jumlah & 160 & 100,00 \\
\hline
\end{tabular}

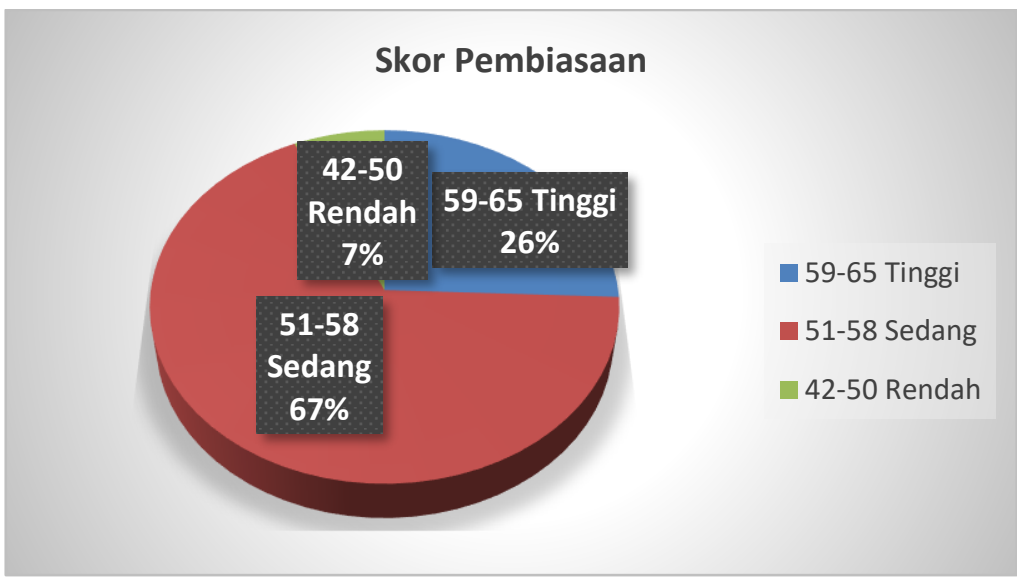

Gambar 2 Kateori Skor Pembiasaan

Dari tabel 1 dan gambar 2 diketahui bahwa dari 160 responden ada 41 orang tua $(25,63 \%)$ memberikan pembiasaan kepada anaknya dalam kategori tinggi, ada 108 orang tua $(67,50 \%)$ memberikan pembiasaan kepada anaknya dalam kategori sedang, dan ada 11 orang tua $(6,88 \%)$ memberikan pembiasaan kepada anaknya dalam kategori rendah. Dari temuan ini diketahui bahwa sebagian besar orang tua memberikan pembiasan kepada anaknya dalam karegori sedang.

\section{Kecerdasan Emosi}

Berdasarkan cara pengelompokkan kategori seperti yang telah dijelaskan pada variabel pembiasaan, maka skor kecerdasan emosi dapat dikelompokkan seperti tabel 2 dan gambar 3.

Tabel 2 Kategori Skor Kecerdasan Emosi 
Pengaruh Pembiasaan, Kecerdasan Emosional dan Dukungan Orang Tua Terhadap Kemandirian Anak DOI: 10.31004/obsesi.v6i4.2301

\begin{tabular}{ccrr}
\hline Skor & Ketagori & Frekuensi & $\%$ \\
\hline $143-160$ & Tinggi & 43 & 26,88 \\
$125-142$ & Sedang & 99 & 61,88 \\
$106-124$ & Rendah & 18 & 11,25 \\
\hline & Jumlah & 160 & 100,00 \\
\hline
\end{tabular}

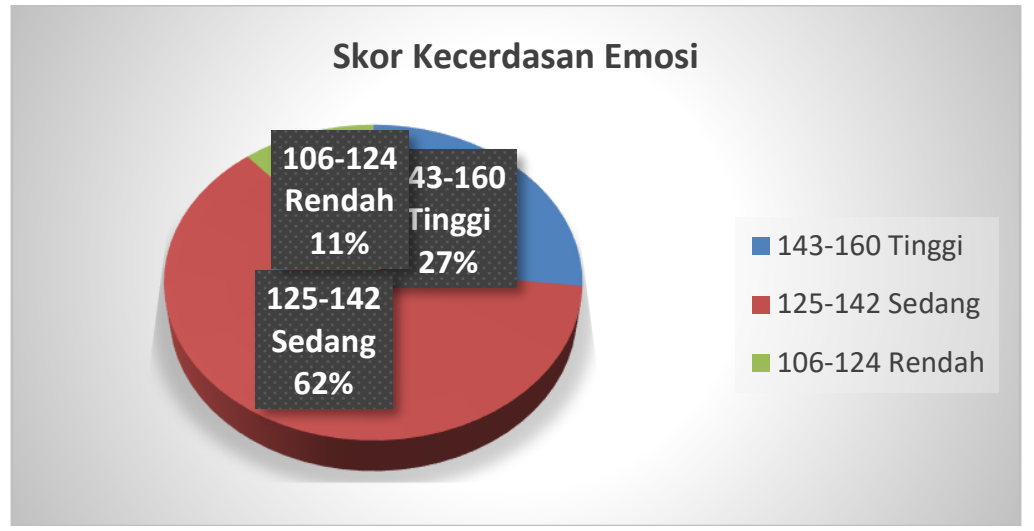

\section{Gambar 3 Kategori Skor Kecerdasan Emosi}

Dari tabel 2 dan gambar 3 diketahui bahwa dari 160 responden ada 43 orang tua $(26,88 \%)$ mengatakan bahwa anaknya memiliki kecerdasan emosi dalam kategori tinggi, ada 99 orang tua $(61,88 \%)$ mengatakan bahwa anaknya memiliki kecerdasan emosi dalam kategori sedang, dan ada 18 orang tua $(11,25 \%)$ mengatakan bahwa anaknya memiliki kecerdasan emosi dalam kategori rendah. Dari temuan ini diketahui bahwa sebagian besar orang tua mengatakan bahwa anaknya memiliki kecerdasan emosi dalam kategori sedang,

\section{Dukungan Orang Tua}

Berdasarkan cara pengelompokkan kategori seperti yang telah dijelaskan pada variabel pembiasaan, maka skor dukungan orang tua dapat dikelompokkan seperti tabel 3 dan gambar 4.

Tabel 3 Kategori Skor Dukungan Orang Tua

\begin{tabular}{|c|c|c|c|}
\hline Skor & Ketagori & Frekuensi & $\%$ \\
\hline $74-80$ & Tinggi & 64 & 40,00 \\
\hline $67-73$ & Sedang & 38 & 23,75 \\
\hline $59-66$ & Rendah & 58 & 36,25 \\
\hline \multicolumn{2}{|c|}{ Jumlah } & 160 & 100,00 \\
\hline
\end{tabular}

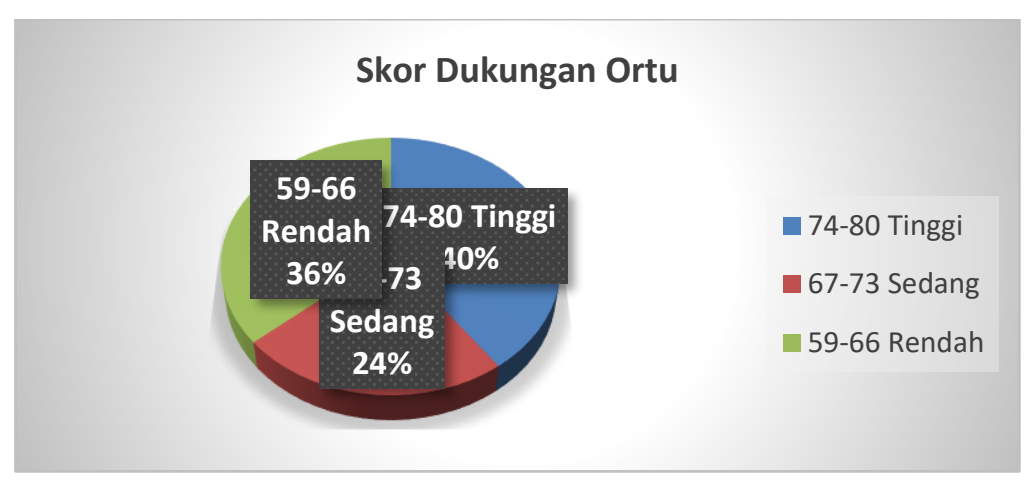

Gambar 4 Kategori Skor Dukungan Orang Tua 
Dari tabel 3 dan gambar 4 diketahui bahwa dari 160 responden ada 64 orang tua (40\%) memberikan dukungan kepada anaknya dalam kategori tinggi, ada 38 orang tua $(23,75 \%)$ memberikan dukungan kepada anaknya dalam kategori sedang, dan ada 58 orang tua $(36,25 \%)$ memberikan dukungan kepada anaknya dalam kategori rendah. Dari temuan ini diketahui bahwa sebagian besar orang tua memberikan dukungan kepada naknya dalam kategori tinggi. Namun demikian, masih banyak juga orang tua yang kurang memberikan dukungan kepada anaknya.

\section{Kemandirian Anak}

Berdasarkan cara pengelompokkan kategori seperti yang telah dijelaskan pada variabel pembiasaan, maka skor kemandirian anak dapat dikelompokkan seperti tabel 4 dan gambar 5 .

Tabel 4 Kategori Skor Kemandirian Anak

\begin{tabular}{ccrr}
\hline Skor & Ketagori & Frekuensi & $\%$ \\
\hline $89-100$ & Tinggi & 36 & 22,50 \\
$76-88$ & Sedang & 110 & 68,75 \\
$63-75$ & Rendah & 14 & 8,75 \\
\hline & Jumlah & 160 & 100,00 \\
\hline
\end{tabular}

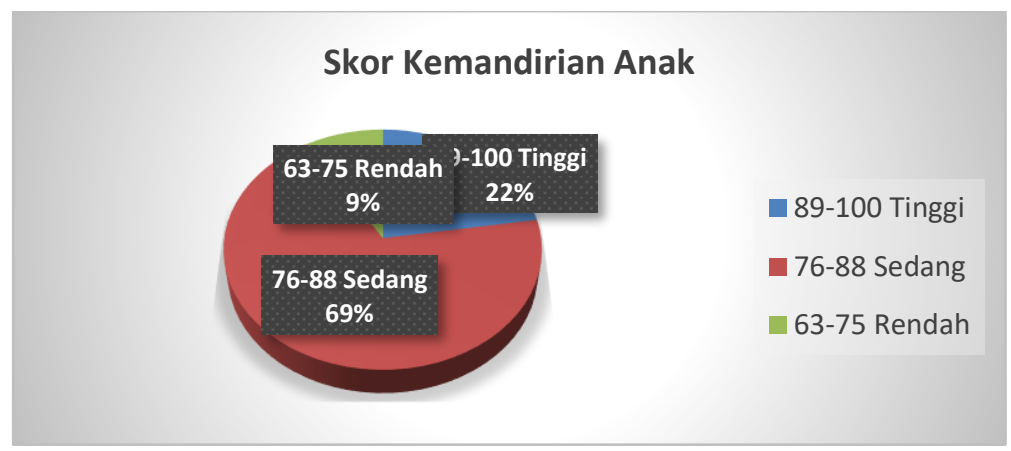

Gambar 5 Kategori Skor Kemandirian Anak

Dari tabel 4 dan gambar 5 diketahui bahwa dari 160 responden ada 36 orang tua $(22,50 \%)$ mengatakan bahwa anaknya memiliki kemandirian dalam kategori tinggi, ada 110 orang tua $(68,75 \%)$ mengatakan bahwa anaknya memiliki kemandirian dalam kategori sedang, dan ada 14 orang tua $(8,75 \%)$ mengatakan bahwa anaknya memiliki kemandirian dalam kategori rendah. Dari temuan ini diketahui bahwa sebagiaan besar orang tua mengatakan bahwa anaknya memiliki kemandirian dalam kategori sedang,

\section{Analisis Regresi Linier Berganda}

Hasil analisis regresi linier berganda disajikan pada tabel 5.

Tabel 5 Hasil Regresi Linier Berganda

\begin{tabular}{|c|c|c|c|c|c|}
\hline \multirow[b]{2}{*}{ Model } & \multicolumn{2}{|c|}{ Unstandardized Coefficients } & \multicolumn{3}{|l|}{$\begin{array}{c}\text { Standardized } \\
\text { Coefficients }\end{array}$} \\
\hline & $\mathrm{B}$ & Std. Error & Beta & $\mathrm{t}$ & Sig. \\
\hline $1 \quad$ (Constant) &,- 029 & 4,317 & &,- 007 & ,995 \\
\hline Pembiasaan & ,397 & 109 & ,242 & 3,637 & ,000 \\
\hline Kecerdasan & 227 & ,044 & ,356 & 5,107 & ,000 \\
\hline Dukungan & 438 & ,085 & 340 & 5,174 & ,000 \\
\hline
\end{tabular}


Berdasarkan hasil analisis Regresi Linier Berganda didapatkan persamaan regresi sebagai berikut:

$$
\mathrm{Y}=-0,029+0,397 \mathrm{X}_{1}+0,227 \mathrm{X}_{2}+0,438 \mathrm{X}_{3}
$$

Dari persamaan garis regresi itu dapat dijelaskan sebagai berikut ini.

1) Nilai konstanta (intercept)

Nilai konstanta atau intercept menunjukkan angka -0,029. Artinya tanpa ada pengaruh variabel pembiasaan $(\mathrm{X} 1)$, kecerdasan emosi $(\mathrm{X} 2)$, dan dukungan orang tua $(\mathrm{X} 3)$, maka kemandirian anak $(\mathrm{Y})$ adalah $-0,029$ atau sangat rendah.

2) Koefisien regresi pembiasaan $\left(X_{1}\right)$

Koefisien regresi pembiasaan $\left(X_{1}\right)$ menunjukkan angka positif 0,397 , berarti variabel pembiasaan memiliki pengaruh positif terhadap kemandirian anak $(\mathrm{Y})$. Jika pembiasaan ditingkatkan, maka kemandirian anak akan meningkat.

3) Koefisien regresi Kecerdasan emosi $\left(X_{2}\right)$

Koefisien regresi kecerdasan emosi $\left(X_{2}\right)$ menunjukkan angka positif 0,227 , berarti variabel kecerdasan emosi memiliki pengaruh positif terhadap kemandirian anak (Y). Jika Kecerdasan emosi semakin tinggi, maka kemandirian anak akan meningkat.

4) Koefisien regresi dukungan orang tua $\left(X_{3}\right)$

Koefisien regresi displin kerja $\left(X_{3}\right)$ menunjukkan angka positif 0,438 , berarti variabel dukungan orang tua memiliki pengaruh positif terhadap kemandirian anak (Y). Jika dukungan orang tua ditingkatkan, maka kemandirian anak akan meningkat.

\section{Uji t}

Berdasarkan analisis didapatkan hasil $\mathrm{t}$ (hitung) seperti pada tabel $5 \mathrm{di}$ atas dapat dijelaskan sebagai berikut ini.

1) Pengaruh pembiasaan terhadap kemandirian anak

Hasil uji $\mathrm{t}$ untuk pengaruh pembiasaan terhadap kemandirian anak menunjukkan nilai $\mathrm{t}$ hitung sebesar 3,637 dengan nilai signifikansi sebesar 0,000 $<0,05$ sehingga pembiasaan memiliki pengaruh positif dan signifikan terhadap kemandirian anak.

2) Pengaruh Kecerdasan emosi terhadap kemandirian anak

Hasil t-hitung untuk pengaruh Kecerdasan emosi terhadap kemandirian anak menunjukkan nilai t-hitung sebesar 5,107 dengan nilai signifikansi sebesar 0,000<0,05. sehingga kecerdasan emosi berpengaruh posiitif dan signifikan terhadap kemandirian anak.

3) Pengaruh dukungan orang tua terhadap kemandirian anak

Hasil t-hitung untuk pengaruh dukungan orang tua terhadap kemandirian anak menunjukkan nilai t-hitung sebesar 5,174 dengan nilai signifikansi sebesar 0,000 < 0,05 sehingga dukungan orang tua berpengaruh positif dan signifikan terhadap kemandirian anak.

\section{Uji F}

Uji F dimaksudkan untuk menguji signifikansi hasil perhitungan korelasi antara semua variabel bebas yaitu pembiasaan, Kecerdasan emosi, dan dukungan orang tua terhadap variabel tergantung yaitu kemandirian anak. Berdasarkan uji F didapatkan hasil seperti tabel 6.

Tabel 6 Hasil Uji F

ANOVA $^{\mathrm{a}}$

\begin{tabular}{lrrrrr}
\hline Model & Sum of Squares & df & Mean Square & \multicolumn{1}{c}{ F } & \multicolumn{1}{c}{ Sig. } \\
\hline 1 Regression & 7138,550 & 3 & 2379,517 & 126,674 &, $000^{\mathrm{b}}$ \\
Residual & 2930,394 & 156 & 18,785 & & \\
Total & 10068,944 & 159 & & & \\
\hline
\end{tabular}

a. Dependent Variable: Kemandirian

b. Predictors: (Constant), Dukungan, Pembiasaan, Kecerdasan 
Pada tabel 6 terlihat bahwa besarnya nilai $\mathrm{F}=126,674$ dengan signifikansi $0,000<0,05$, sehingga secara bersama-sama variabel pembiasaan, kecerdasan emosi, dan dukungan orang tua berpengaruh signifikan terhadap kemandirian anak.

\section{Uji Koefisien Determinasi}

Hasil uji koefisien determinansi disajikan pada tabel 7.

Tabel 7 Hasil Uji Koefisien Determinan Model Summary ${ }^{b}$

\begin{tabular}{lr|r|r|r}
\hline Model & $\mathrm{R}$ & \multicolumn{1}{c}{ R Square } & Adjusted R Square & Std. Error of the Estimate \\
\hline 1 &, $842^{\mathrm{a}}$ &, 709 &, 703 & 4,33412 \\
\hline
\end{tabular}

a. Predictors: (Constant), Dukungan, Pembiasaan, Kecerdasan

b. Dependent Variable: Kemandirian

Pada tabel 7 diketahui bahwa $\mathrm{R}^{2}$ (Adjusted $R$ square) didapatkan hasil sebesar 0,703 atau $70,3 \%$. Hal ini berarti secara bersama-sama variabel pembiasaan, kecerdasan emosi, dan dukungan orang tua berpengaruh terhadap kemandirian anak sebesar 70,3\% dan sisanya sebesar $29,7 \%$ dipengaruhi oleh variabel lain yang tidak diteliti.

\section{Pembahasan \\ Pengaruh Pembiasaan terhadap Kemandirian Anak}

Koefisien regresi pembiasaan menunjukkan angka positif 0,397, berarti variabel pembiasaan memiliki pengaruh positif terhadap kemandirian anak (Y). Jika pembiasaan ditingkatkan, maka kemandirian anak akan meningkat. Hasil uji $t$ untuk pengaruh pembiasaan terhadap kemandirian anak menunjukkan nilai t hitung sebesar 3,637 dengan nilai signifikansi sebesar 0,000 $<0,05$ sehingga pembiasaan memiliki pengaruh positif dan signifikan terhadap kemandirian anak. Hasil penelitian ini sejalan dengan hasil penelitian Pramono et.al yang menjelaskan bahwa kemandirian anak contohnya buang air kecil (BAK) dan buang air besar (BAB) pembiasaan pada aktivitas ini juga harus dilatih dalam menggunakan toilet. Latihan penggunaan toilet adalah sebuah usaha pembiasaan mengontrol BAB dan BAK secara benar dan teratur (Pramono et al., 2018). Sejalan juga dengan hasil penelitian Danauwiyah \& Dimyati, yang mengatakan kemandirian anak dapat dilihat dari anak melakukan hal yang mereka butuhkan untuk bertahan hidup seperti menyiapkan makan, memasang kancing, mengikat tali sepatu, mencuci tangan, dan lain-lain (Danauwiyah \& Dimyati, 2021)

Kemandirian anak dapat dipengaruhi oleh pembiasaan. Pembiasaan itu sendiri adalah (habituation) proses pembentukan sikap dan perilaku yang relatif menetap dan bersifat otomatis melalui proses pembelajaran yang berulang-ulang. Sikap atau perilaku yang menjadi kebiasaan mempunyai ciri; perilaku tersebut relatif menetap, umumnya tidak memerlukan fungsi berpikir yang cukup tinggi. Ramayulis menjelaskan bahwa pembiasaan adalah upaya praktis dalam pembinaan dan pembentukan mental dan akhlak. Hasil dari pembiasaan yang dilakukan oleh pendidik adalah terciptanya suatu kebiasaan bagi anak didik. Kebiasaan adalah suatu tingkah laku tertentu yang sifatnya otomatis, tanpa direncanakan terlebih dahulu, dan berlaku begitu saja tanpa dipikirkan lagi (Ramayulis, 2018).

Proses pembiasaan sebenarnya berintikan pengulangan. Artinya yang dibiasakan itu adalah sesuatu yang dilakukan berulang-ulang dan akhirnya menjadi kebiasaan. Pembiasaan harus diterapkan dalam kehidupan keseharian anak didik, sehingga apa yang dibiasakan terutama yang berkaitan dengan akhlak baik akan menjadi kepribadian yang sempurna. Misalnya jika guru masuk kelas selalu mengucapkan salam. Proses pembiasaan dalam pendidikan merupakan hal yang penting terutama bagi anak-anak usia dini. Anak-anak belum menyadari apa yang disebut baik dan tidak baik dalam arti susila. Ingatan anak-anak belum kuat, perhatian mereka lekas dan mudah beralih kepada hal-hal yang terbaru dan 
disukainya. Dalam kondisi ini mereka perlu dibiasakan dengan tingkah laku, keterampilan, kecakapan dan pola pikir tertentu.

Pembiasan yang baik akan berhasil apabila dilakukan dengan penguatan. Menurut Syafril penguatan adalah dampak dari kemungkinan suatu perilaku akan diulang atau tidak diulang oleh anak. Konsekuensi yang menyenangkan dari perilaku tertentu akan membuat seseorang cenderung mengulanginya (Amini \& Mariyati, 2021).

\section{Pengaruh Kecerdasan Emosi terhadap Kemandirian Anak}

Koefisien regresi kecerdasan emosi menunjukkan angka positif 0,227, berarti variabel kecerdasan emosi memiliki pengaruh positif terhadap kemandirian anak (Y). Jika Kecerdasan emosi semakin tinggi, maka kemandirian anak akan meningkat. Hasil t-hitung untuk pengaruh Kecerdasan emosi terhadap kemandirian anak menunjukkan nilai t-hitung sebesar 5,107 dengan nilai signifikansi sebesar 0,000<0,05. sehingga kecerdasan emosi berpengaruh posiitif dan signifikan terhadap kemandirian anak.

Selain faktor pembiasaan, faktor yang dianggap berpengaruh terhadap kemandirian anak adalah kecerdasan emosional. Hasil penelitian (Siregar, 2018) menyimpulkan bahwa kecerdasan emosional berpengaruh terhadap kemandirian santriwan sebesar $41,3 \%$ dan santriwati sebesar 33,9\%. Penelitian (Hidayati, 2014) juga menyimpulkan bahwa kecerdasan emosi berkorelasi dengan kemandirian. Goleman menyebutkan bahwa individu yang cerdas secara emosi mempunyai kemampuan untuk mengenali emosi diri sendiri dan orang lain, mengelola emosi diri sendiri, motivasi, mengenali emosi orang lain dan kemampuan membina hubungan (Goleman, 2016).

Menurut Shapiro, kecerdasan emosional sebagai dasar kecerdasan sosial yang melibatkan kemampuan memantau perasaan dan emosi baik pada diri sendiri maupun pada orang lain, memilah-milah semuanya dan menggunakan informasi untuk membimbing pikiran dan tindakan. Kecerdasan emosional inilah yang berfungsi sebagai pengendalian diri seseorang dalam melakukan tindakan. Kecerdasan emosional diungkapkan pertama kali oleh psikolog Peter Salovy dari Harvard University dan John Mayer dari University Of New Hampshire untuk mengungkapkan kualitas-kualitas emosional yang tampaknya penting bagi keberhasilan hidup. Kualitas ini antara lain empati, mengungkapkan dan memahami perasaan, mengendalikan amarah, kemandirian, kemampuan menyesuiakan diri, kemampuan memecahkan masalah antar pribadi, ketekunan, kesetiakawanan, keramahan dan sikap hormat (Shapiro, 2018).

Menurut Riana berbagai penelitian dalam bidang psikologi telah membuktikan bahwa anak-anak yang memiliki kecerdasan emosi yang tinggi adalah anak-anak yang bahagia, percaya diri, populer dan sukses. Sedangkan menurut Permendikbud No 137 tahun 2014 tentang Standar Tingkat Pencapaian Perkembangan Anak (STPPA), standar pencapaian perkembangan pada aspek sosial emosional antara lain: menunjukan sikap mandiri, menunjukan rasa percaya diri, memahami peraturan dan disiplin, memiliki sikap gigih (tidak mudah menyerah), dan bangga terhadap hasil karya sendiri.

Megan M. McClelland \& Tominey menambahkan bahwa anak-anak harus memahami apa yang mereka alami dan menjadikan sebagai informasi yang dapat digunakan untuk mengatur pikiran, emosi dan perilaku mereka (Lau et al., 2021).

\section{Pengaruh Dukungan Orang Tua terhadap Kemandirian Anak}

Koefisien regresi dukungan orang tua menunjukkan angka positif 0,438, berarti variabel dukungan orang tua memiliki pengaruh positif terhadap kemandirian anak (Y). Jika dukungan orang tua ditingkatkan, maka kemandirian anak akan meningkat. Hasil t-hitung untuk pengaruh dukungan orang tua terhadap kemandirian anak menunjukkan nilai t-hitung sebesar 5,174 dengan nilai signifikansi sebesar 0,000 $<0,05$ sehingga dukungan orang tua berpengaruh positif dan signifikan terhadap kemandirian anak. 
Selain faktor pembiasaan dan kecerdasan emosional, kemadirian anak juga dapat dipengaruhi oleh dukungan orang tua. Noorkasiani dalam (Ningtyas, 2017)menyebutkan bahwa dukungan keluarga merupakan unsur penting dalam membantu individu menyelesaikan masalah. Apabila ada dukungan, rasa percaya diri akan bertambah dan motivasi untuk mengatasi masalah yang terjadi akan meningkat. Hasil penelitian (Ningtyas, 2017) menyimpulkan bahwa terdapat hubungan antara dukungan keluarga dengan kemandirian activities of daily living pada anak prasekolah di KB dan TK Sanggar Sahabat Sejati Yogyakarta. Hasil penelitian (Garnika \& Suarti, 2018) menyimpulkan bahwa dukungan orang tua berpengaruh terhadap kemandirian anak. Muncsh menjelaskan bahwa lingkungan keluarga merupakan lingkungan utama bagi anak untuk belajar mengenai norma, nilai, sikap, dan kepercayaan budaya mereka sehingga anak-anak tumbuh menjadi anak yang memiliki sikap positif untuk bertindak dalam lingkungan yang lebih luas setelahnya (Pagarwati \& Rohman, 2021).

Menurut Vasilyevaa dan Shcherbakovb, orangtua adalah pembentuk kepribadian anak, sehingga orangtua harus dapat menjadi teladan bagi anak-anaknya, terlebih pada masa anak memasuki usia prasekolah (Jeti et al., 2021). Hasil penelitian (Jeti et al., 2021) menyimpulkan bahwa keluarga memiliki peranan penting dalam menanamkan nilai-nilai ini sebagai dasar pendidikan karakter melalui pembiasaan dan keteladanan sejak usia dini dalam kehidupan sehari-hari yaitu dengan membiasakan dan mencotohkan perilaku saling menyayangi, menghormati antara sesama, saling menjaga martabat, saling melindungi, bekerjasama dan berempati. Penerapan nilai-nilai ini dapat membentuk anak menjadi pribadi yang berkarakter.

Hayati mengatakan bahwa sikap orang tua sangat membantu dalam mengembangkan potensi anak, di antaranya yakni menghargai opini anak serta mendorong anak untuk mengutarakannya, menyediakan kesempatan bagi anak-anak dalam melakukan perenungan, khayalan, berpikir, serta memperbolehkan anak dalam pengambilan keputusan secara individu dan memberi stimulus padanya agar senantiasa banyak bertanya serta memberi penguatan pada anak bahwasannya sikap orang tua menghargai rasa ingin mencoba hal baru, dilaksanakan dan menghasilkan, menunjang dan mendorong kegiatan anak, menikmati keberadaannya bersama anak, memberi sanjungan yang sungguh-sungguh kepada anak, mendorong kemandirian anak dalam bekerja dan menjalin hubungan kerja sama yang baik dengan anak (Lilawati, 2021). Hasil penelitian (Utami \& Prasetyo, 2021) menyimpulkan bahwa perkembangan karakter disiplin anak dipengaruhi oleh pola pengasuhan yang diterima dari orang tua. Bentuk pengasuhan yang yang beragam memberikan pengaruh yang berbeda pula terhadap anak.

Kusumaningtyas menjelaskan bahwa pada dasarnya sebagai orang tua berkewajiban untuk memberi kasih sayang dan perhatian pada anak-anaknya. Namun demikian kasih sayang dan perhatian yang diberikan pada anaknya tidak boleh terlalu berlebihan, karena dapat menghambat perkembangan kemandirian. Bagi para orang tua, mengirimkan anakanak ke sekolah sudah merupakan sebuah kewajiban yang disertai harapan-harapan agar si anak dapat memeperoleh wawasan, dunia baru, hidup bersosial, ilmu-ilmu yang intinya demi mempersiapkan mereka menghadapi masa depan mereka dengan baik. Kalau dilihat dari sisi seorang anak, pada awalnya pergi ke sekolah adalah suatu aktifitas baru dari yang biasa mereka dapatkan di seputar rumah dan orang tua, masuk ke lingkungan baru yang masih menjadi tanda tanya. Lingkungan yang biasa mereka rasakan aman di rumah, dunia yang sudah dan biasa mereka kenal sejak lahir, yang tidak banyak berhubungan dengan dunia luar. Sering ditemui hari-hari pertama anak di play group atau TK diiringi dengan tangis. Mereka memiliki ketakutan, kecemasan, kekhawatiran akan situasi baru, wawasan baru, lingkungan baru, tuntutan baru. Sebab itu, perlu bagi para orang tua mempersiapkan mereka dengan baik secara mental untuk masuk ke sekolah (Anwar \& Ahmad, 2016). 


\section{Pengaruh Pembiasaan, Kecerdasan Emsi, dan Dukungan Orang Tua Secara Bersama-sama terhadap Kemandirian Anak}

Besarnya nilai $\mathrm{F}=126,674$ dengan signifikansi $0,000<0,05$, sehingga secara bersamasama variabel pembiasaan, kecerdasan emosi, dan dukungan orang tua berpengaruh signifikan terhadap kemandirian anak. Angka $\mathrm{R}^{2}$ (Adjusted $R$ square) didapatkan hasil sebesar 0,703 atau $70,3 \%$. Hal ini berarti secara bersama-sama variabel pembiasaan, kecerdasan emosi, dan dukungan orang tua berpengaruh terhadap kemandirian anak sebesar 70,3\% dan sisanya sebesar 29,7\% dipengaruhi oleh variabel lain yang tidak diteliti.

Ada sejumlah faktor yang mempengaruhi kemandirian (Ali \& Asrori, 2014): (1) Gen atau keturunan orang tua. Orang tua yang memiliki sifat kemandirian tinggi sering kali menurunkan anak yang memiliki kemandirian juga. Namun, masih menjadi perdebatan karena ada yang berpendapat bahwa sesungguhnya bukan sikap kemandirian orang tuanya yang menurun pada anaknya melainkan sikap orang tuanya muncul berdasarkan cara orang tua mendidik anaknya; (2) Pola asuh orang tua. Cara orang tua mengasuh dan mendidik anak akan mempengaruhi perkembangan kemandirian anak. Orang tua yang terlalu banyak melarang atau mengeluarkan kata-kata "jangan" kepada anak tanpa disertai dengan penjelasan yang rasional akan menghambat kemandirian anak, sebaliknya orang tua yang menciptakan rasa aman dalam interaksi keluarganya akan dapat mendorong kelancaran perkembangan anak. Demikian juga orang tua yang cenderung sering membandingbandingkan anak yang satu dengan anak yang lainnya juga akan berpengaruh kurang baik pada perkembangan kemnadirian anak; (3) Sistem pendidikan di sekolah. Proses pendidikan di sekolah yang tidak mengembangkan demokrasi pendidikan akan cenderung menekankan indoktrinasi tanpa argumentasi akan menghambat perkembangan kemandirian anak sebagai siswa. Demikian juga proses pendidikan yang banyak menekankan kepentingan pemberian sanksi atau hukuman juga dapat menghambat kemandirian anak. Sebaliknya proses pendidikan yang lebih menekankan pentingnya penghargaan pada potensi anak, pemberian reward dan menciptakan kompetisi positif akan memperlancar perkembangan kemandirian anak; (4) Sistem kehidupan di masyarakat. Sistem kehidupan masyarakat yang terlalu menekankan pentingnya struktur sosial, kurang aman serta kurang menghargai manivestasi potensi anak dalam kegiatan produktif dapat menghambat kelancaran kemandirian anak. Sebaliknya, lingkungan masyarakat yang aman menghargai ekspresi potensi anak dalam bentuk berbagai kegiatan dan tidak terlalu herarkis akan mendorong perkembangan kemandirian anak.

Sedangkan Nasution dalam (Hasanah, 2012) mengelompokkan faktor yang memengaruhi kemandirian anak menjadi dua kelompok, yaitu: (1) Faktor eksogen, faktor eksogen merupakan faktor yang berasal dari luar yaitu yang berasal dari keluarga, sekolah, masyarakat dan kelompok teman sebaya; (2) Faktor endogen, faktor endogen merupakan faktor yang berasal dari dalam individu yaitu faktor fisiologis dan faktor psikologis. Faktor fisiologis diantaranya kondisi fisik sehat dan tidak sehat atau sempurna dan tidak sempurna, sedangkan faktor psikologis meliputi: bakat, minat, motivasi, IQ dan kepribadian.

\section{SIMPULAN}

Berdasarkan hasil penelitian ini dapat ditarik suatu kesimpulan: (1) Pembiasaan sikap dan perilaku yang baik kepada anak yang ditanamkan sejak diri, terus-menerus, dan konsisten dapat membentuk perilaku mandiri pada anak; (2) Anak yang memiliki kecerdasan emosional yang tinggi akan mampu merasakan dan mengekspresikan emosi dengan tepat sesuai situas, tidak mudah marah, dapat beradaptasi dengan situasi dan kondisi, serta dapat berteman baik dengan teman sebayanya, akan mendorong sikap dan perilaku anak tersebut menjadi lebih mandiri; (3) Pemberian dukungan orang tua kepada anak saat melakukan kegiatan atau upaya untuk belajar mandiri, dengan cara memberikan pujian, belaian tangan, dan komunikasi personal secara intensif, dapat menjadi faktor penguat bagi anak untuk lebih semangat untuk segera dapat memiliki sikap dan perilaku mandiri. 


\section{UCAPAN TERIMA KASIH}

Peneliti mengucapkan terima kasih kepada kepala sekolah, guru dan orang tua anak yang telah berpartisipasi aktif membantu pengisian kuesioner.

\section{DAFTAR PUSTAKA}

Ali, M., \& Asrori, M. (2014). Psikologi Perkembangan Remsjs. Bumi Aksara.

Amin, M., Kristiana, D., \& Fadlillah, M. (2021). Jurnal Obsesi : Jurnal Pendidikan Anak Usia Dini Pengaruh Kelekatan Aman Anak pada Ibu terhadap Kemandirian Anak Usia 5-6 Tahun Abstrak. 5(1), 127-134. https:// doi.org/10.31004/obsesi.v5i1.504

Amini, M., \& Mariyati. (2021). Meningkatkan Karakter Anak Usia Dini melalui Pemberian Penguatan. 5(2), 2101-2113. https://doi.org/10.31004/obsesi.v5i2.1128

Anhusadar, L. O., \& Islamiyah. (2021). Jurnal Obsesi : Jurnal Pendidikan Anak Usia Dini Penerapan Perilaku Hidup Bersih dan Sehat Anak Usia Dini di Tengah Pandemi Covid 19 Abstrak. 5(1), 463-475. https://doi.org/10.31004/obsesi.v5i1.555

Anwar, \& Ahmad, A. (2016). Pendidikan Anak Usia Dini. Alfabeta.

Danauwiyah, N. M., \& Dimyati, D. (2021). Kemandirian Anak Usia Dini di Masa Pandemi Covid-19. Jurnal Obsesi: Jurnal Pendidikan Anak Usia Dini, 6(2), 588-600. https://doi.org/10.31004/obsesi.v6i2.994

Garnika, E., \& Suarti, N. K. A. (2018). Pengaruh Dukungan Orang Tua Terhadap Kemandirian Anak Usia Dini di PAUD Permata Bangsa. Jurnal Realita, 3(5), 1-7. https:// doi.org/10.17509/cd.v7i2.10529

Goleman, D. (2016). Emotional Intelligence, Kecerdasan Emosional Mengapa EI Lebih Penting daripada IQ. Gramedia Pustaka Utama.

Hasanah, A. R. (2012). Hubungan Antara Kemandirian Dengan Penyesuaian Diri Pada Siswa Pondok Pesantren. Fakultas Psikologi Universitas Muhammadiyah Surakarta, 1-7.

Hayati, D. (2020). Jurnal Obsesi : Jurnal Pendidikan Anak Usia Dini Proses Penerapan Etika Bertoilet pada Anak Usia Dini Abstrak. 4(1), 316-325. https:// doi.org/10.31004/obsesi.v4i1.334

Hayati, F., \& Hanum, C. F. (2017). Persepsi Guru PAUD Terhadap Kegiatan Bermain Peran Sebagai Stimulus Kemandirian Anak Usia Dini. Jurnal Psikologi Indonesia, 4(2), 1-8.

Hidayati, N. I. (2014). Pola Asuh Otoriter Orang Tua, Kecerdasan Emosi, dan Kemandirian Anak SD. Persona, Jurnal Psikologi Indonesia, 3(1), 1-8. https:// doi.org/10.30996/persona.v3i01.364

Jeti, L., Manan, Risman, K., \& Edison. (2021). Jurnal Obsesi : Jurnal Pendidikan Anak Usia Dini Application of Philosophy Values of Bhinci-Bhinciki Kuli in Early Childhood at Wolio Community Abstrak. 5(1), 530-537. https://doi.org/10.31004/obsesi.v5i1.643

Kurniati, E., Kusumanita, D., Alfaeni, N., \& Andriani, F. (2021). Jurnal Obsesi : Jurnal Pendidikan Anak Usia Dini Analisis Peran Orang Tua dalam Mendampingi Anak di Masa Abstrak. 5(1), 241-256. https://doi.org/10.31004/obsesi.v5i1.541

Kusumaningtyas, L. E. (2015). Dampak Overprotektif Terhadap Perkembangan Kemandirian Anak. Widya Wacana, 10(1), 1-12.

Latan, H., \& Temalagi, S. (2018). Analisis Multivariate. Alfabeta.

Lau, Y. S., Rahardjo, M. M., Guru, P., Anak, P., Dini, U., Kristen, U., \& Wacana, S. (2021). Meningkatkan Budaya Antri Anak Usia 4-5 Tahun melalui Metode Berbaris Sesuai Warna. 5(1), 755-762. https:// doi.org/10.31004/obsesi.v5i1.624

Lilawati, A. (2021). Jurnal Obsesi : Jurnal Pendidikan Anak Usia Dini Peran Orang Tua dalam Mendukung Kegiatan Pembelajaran di Rumah pada Masa Pandemi Abstrak. 5(1), 549558. https:// doi.org/10.31004/obsesi.v5i1.630

Ningtyas, B. T. (2017). Hubungan Dukungan Keluarga Dengan Kemandirian Activities Of Daily Living Pada Anak Prasekolah Di KB dan TK Sanggar Sahabat Sejati Yogyakarta. Program Studi Ilmu Keperawatan Fakultas Ilmu Kesehatan Universitas 'Aisyiyah Yogyakarta. 
Pagarwati, L. D. A., \& Rohman, A. (2021). Grandparenting Membentuk Karakter Anak Usia $\begin{array}{llll}\text { Dini di Masa Pandemi } & \text { Covid-19. } & \text { 1229-1239. }\end{array}$ https://doi.org/10.31004/obsesi.v5i2.831

Pramono, D., Risnawati, A., \& Siliwang, I. (2018). Jurnal Obsesi : Jurnal Pendidikan Anak Usia Dini Research \& Learning in Early Childhood Education Meningkatkan Kedisiplinan Anak Usia Dini Melalui Latihan Pembiasaan Penggunaan Toilet di KB Al-Hidayah Insan Mandiri Kabupaten Bandung * Corresponding author: Dikdik Pramono. 2(1), 64-69. https://doi.org/10.31004/obsesi.v2i1.8

Purnama, S., \& Hidayati, L. (2020). Jurnal Obsesi : Jurnal Pendidikan Anak Usia Dini Pengasuhan Anak Usia Dini dalam Hikayat Indraputra. 4(2), 520-542. https://doi.org/10.31004/obsesi.v4i2.391

Ramayulis. (2018). Ilmu Pendidikan Islam. Kalam Mulia.

Sa'diyah, R. (2017). Pentingnya Melatih Kemandirian Anak. Kordinat, XVI(1), 31-46. https://doi.org/10.15408/kordinat.v16i1.6453

Sari, C. R., Hartati, S., \& Yetti, E. (2019). Jurnal Obsesi : Jurnal Pendidikan Anak Usia Dini Peningkatan Perilaku Sosial Anak melalui Permainan Tradisional Sumatera Barat. 3(2), 416-424. https:// doi.org/10.31004/obsesi.v3i2.225

Setiani, I., \& Setyo, A. (2014). Upaya Meningkatkan Kemandirian Anak Melalui Media Pilar Karakter 2 Pada TK B Di RA Nusantara 02 Semarang. Jurnal Penelitian PAUDIA, 1(1), 1-6.

Shapiro, L. E. (2018). Mengajarkan Emotional Intellegence. Gramedia Pustaka Utama.

Siahaan, Y. E., Sutapa, P., \& Yus, A. (2021). Pengaruh Komunikasi Orangtua terhadap Perilaku Agresif verbal Anak Usia 5-6 Tahun. 5(2), 1472-1486. https://doi.org/10.31004/obsesi.v5i2.890

Siregar, A. B. (2018). Pengaruh Kecerdasan Emosional, Kecerdasan Spiritual Dan Motivasi Berprestasi Terhadap Kemandirian Santriwan-Santriwati Muhammadiyah Boarding School Prambanan Yogyakarta. G-COUNS: Jurnal Bimbingan Dan Konseling, 2(2), 116. https:// doi.org/10.31316/g.couns.v2i2.70

Sit, M. (2015). Psikologi perkembangan anak usia dini. Perdana publishing.

Srianita, Y., Ruf, M., \& Meilanie, S. M. (2020). Jurnal Obsesi : Jurnal Pendidikan Anak Usia Dini Pembentukan Karakter dalam Pendidikan Makan ( Studi Kasus di Raudhatul Athfal Istiqlal Jakarta ). 4(1), 152-161. https:// doi.org/10.31004/obsesi.v4i1.277

Sugiyono. (2013). Metode Penelitian Pendidikan. Alfabeta.

Susanto, A. (2018). Pendidikan Anak Usia Dini. Bumi aksara.

Utami, F., \& Prasetyo, I. (2021). Pengasuhan Keluarga terhadap Perkembangan Karakter Disiplin Anak Usia Dini. 5(2), 1777-1786. https:// doi.org/10.31004/obsesi.v5i2.985

Wijayanti, D. S. (2020). Kegiatan Pembiasaan Prapembelajaran untuk Meningkatkan Karakter Siswa di MI Diponegoro 1 Purwokerto Lor, Kecamatan Purwokerto Timur, Kabupaten Banyumas. Institut Agama Islam Negeri.

Yusuf, S. (2019). Psikologi Perkembangan Anak \& Remaja. Rosdakarya. 